\title{
Antecedents and Consequences of Organizational Fear and Silence Behavior: Evidence Service Sector from Turkey
}

\author{
Cengiz Mengenci ${ }^{1}$ \\ ${ }^{1}$ Faculty of Business Administration, Bursa Orhangazi University, Turkey \\ Correspondence: Cengiz Mengenci, Faculty of Business Administration, Bursa Orhangazi University, Bursa, \\ Turkey. Tel: 905-054-075-071. E-mail: cengiz.mengenci@bou.edu.tr
}

Received: March 25, 2015

Accepted: April 7, 2015

Online Published: April 25, 2015

doi:10.5539/ibr.v8n5p223

URL: http://dx.doi.org/10.5539/ibr.v8n5p223

\begin{abstract}
This study aims to understand relationships between organizational climate, job satisfaction, stress, fear and silence behavior. For this purposes, Vakola and Bouradas (2005) organizational silence climate survey, Dyne et al. (2003) Employee Silence Behavior scale, Brown and Peterson' (1994) job satisfaction survey and House and Rizzo (1972) Stress scale were administered. 186 surveys returned and used to analyze to figure out variables relationships. Regression and correlation statistical analysis were applied. Analysis results show that organizational silence behavior shape employee silence behavior. But employee silence behavior only has a negative relationship with stress. On the other hand, no relation was found between employee silence and job satisfaction.
\end{abstract}

Keywords: organizational silence behavior, employee silence behavior, job satisfaction, stress

\section{Introduction}

Information is getting harder to find and store to use it when organization needs. Today global market seeks to find right type of information to use having a competitive advantage and sustaining that competitive advantage. And also, sometimes in organization, every decision, made by the strategy makers could not be appropriate for the benefits of organization. Or sometimes, some factor, coming from organization environment would really damage organization benefits. In all mention situations, organization needs someone to share the needy information timely manner and also prevent organization strategy makers from mistakes. To make this happen in organization settings, organization should give the employee permission to voice up. If reverse condition exits, so many severe thing can happen and this cause organization loosing reputation, competitive advantage, and profit.

Researchers have been trying to understand why organization members abstain from talking or warning about anything which might worsen the situation of the organization in the market (Morrison \& Milliken, 2000). Researchers define this phenomenon as silence climate. Silence climate happens because of fear (Pinder \& Harlos, 2001). Morrison and Milliken (2000) said that when most members of an organization choose to keep silent about organizational matters, silence becomes a collective behavior, which is referred to as organizational silence. This means that organizational silence is first chosen by the employees due to some of the situation.

This research aims to understand how organizational climate affects and feeds silence behavior and how silence behavior affects the consequences such as job satisfaction or stress. There is little empirical evidence in the literature which explains the relationship between these variable. This study wants to explore this entire subject and fill missing gap in the literature.

\section{Literature Review}

Organization strives to have competitive advantage and sustain it. To make it happen, organization needs educated, skilled, talented, and committed employee. But, even if organizations have a right type of employee, they have to find the way to use employee's resource as good as they can. Solution might be having an environment in organization that supports the employee share their knowledge easily with multi-ways communication opportunity, and voice up about every matter. On the other hand sometimes employee might not agree to share their information and hold their opinion about any matter related to organization. Researchers have tried to understand why employee does not prefer to share their opinions. Morrison and Milliken (2000) 
first introduced silence behavior in organizational behavior field. And they defined this phenomenon that employee withholds their idea and concerns the organizational problems. Bowen and Blackmon (2003) defined this collective phenomenon such as employee choice which employee strains from expressing their opinion about anything related to organizational issue.

And also some other studies grouped reasons behind silence behavior in such as organizational, management, individual and cultural factors (Milliken et al., 2003; Premeaux, 2001; Pinder \& Harlos, 2001; Bowen \& Blackmon, 2003). Organizational factors are injustice culture, silence climate. Management factors are managers fear of getting negative feedback, prejudice about employee, personality of managers, homogeneity of management board. Individual factors are lack of trust between employee to employee and employee to managers, risky to talk, fear of isolation, old experience, fear of hurting relationships, personality of employee. And the last factors are national cultural reasons such as different cultural norms and high power distance.

From all definitions, it may be understood that everything starts with choosing to hide employee own ideas then this behavior spreads throughout all organizations and becomes organization wide problems (Bowen \& Blackmon, 2003). After starting phase, this situation may worsen. It starts not to talk about one issue then it becomes not to talk about anything related to organizational issue (Ellis \& Dyne, 2009). In this phase, actually silence becomes organizational climate (Pinder \& Harlos, 2001). Then even if they trust their knowledge and experience, employee may think sharing opinion is too risky (Premeaux \& Bedeian, 2003). And also they may feel that they may lose promotion opportunities, accepted as a troublemaker, and not be seen as a member of specific organizations (Vakola \& Bouradas, 2005).

As it was said before, when silence behavior is shared by all organization member, then it becomes organizational climate (Blatt et al., 2006; Gephart et al., 2009). There are three important factors which foster the organizational silence behavior. They are the top management attitude to silence, supervisor attitude to silence and communication opportunities (Mayhew et al., 2006).

Diversity in employee source who propose different looking's, different opinions are important factor for organization to make a right strategy, but top manager might not accept this way. And he/she might see them as a threat who questions their authority. If this type of understanding exists in organizations that means, managers have classical management philosophy and McGregor x type employee perception. Under this philosophy, managers think that they know everything better than any employee, want to have strict control over everybody, resist or intolerant other idea, not to let employee have open communication channel to express their feeling and never accept contribution from them (Slade, 2008; Breen et al., 2005; Sussman, 2008). That's why top management attitude to silence is accepted as the most important and effective factor to support silence behavior in organization (Vakola \& Bouradas, 2005).

In micro level, supervisor attitude to silence is important. Because first line employee is the core of the workforce which gives their valuable feedbacks and opinion directly to the supervisor. If supervisor supports the first line employee with multichannel communication opportunities, this means employee can easily express their feeling, opinion and discuss the issue related to their self and organization and also feel like a team (Tangirala \& Ramanujam, 2008; Dutton \& Ashford, 1999, Grenville, 2007). If opposite is occurred, employee might prefer to be silence. And they hold to express their opinion which might be important for having a competitive advantage and sustain it.

Today's world, employee contribution is highly important aspects to find right solution to all problem and make a right strategy. To make those happen, only solution is to support organization workers with a multichannel communication opportunities. If organization support their employee with communication channel, employee can easily transfer their experience and knowledge throughout organization and make organization change and adapt faster (Ruppel \& Harrington, 2000; Johlke \& Duhan, 2000). And also the more employee talks and share their idea and their feeling the more they feel as a team and in secure (Botero \& Dyne, 2009).

So many reasons make employee to abstain from sharing experience, knowledge and opinion. This is called as an employee silence behavior. Employee silence behavior phenomenon is defined such as employee who has an ability to change something prefers to hide their behavioral preferences, cognitive evaluation and sincere emotion from everybody and not to share them with anyone (Pinder \& Harlos, 2001). Researcher has categorized this phenomenon in to three dimensions.

First one is Defensive Silence which was defined as resist to share relevant ideas, information, or opinions to protect their selves, due to fear. Defensive Silence is purposeful and proactive behavior that is targeted to protect the self from external threats (Schlenker \& Weigold, 1989). 
Second is Acquiescent Silence, which was explained intentionally passive and uninvolved behavior. For example, an employee might think that speaking up would not solve or change anything that's why employee might accept talking worthless. Also, an employee might keep opinions and information to him/her self, based on low self-efficacy assessments about personal capability to affect the situation.

And the last one is Pro-social Silence which was defined as expressing work-related ideas, information, or opinions based on cooperative motives. This type of voice behavior is intentional, proactive, and other-oriented. This silence behavior prioritizes advantage of others, such as the organization or colleges. This is because many employees in organizations (especially those with power) are comfortable with things the way they are and prefer to maintain the status quo (Nemeth \& Staw, 1989).

Consequences of employee silence behavior are stress, job dissatisfaction, employee turnover intend, sabotage and so many negative results might be occurred (Perlow \& Williams, 2003).

As it is understood from all information, these hypotheses can be driven

$h_{1}$. Organizational silence behavior has a positive relation with employee silence behavior.

$\mathrm{h}_{2}$. Employee silence behavior has a positive relation with job satisfaction but negative relation with stress.

\section{Method}

\subsection{Subjects and Procedures}

Data were collected from service sector in Bursa-Turkey. A questionnaire survey was conducted. The questionnaires that include demographic information, organizational silence behavior, employee silence behavior, job satisfaction, stress items were delivered to 250 randomly selected service workers in 5 different companies. 186 surveys came back from companies and accepted to analyze. The sample included female $48.3 \%$ and male $51.7 \%$. The majority of the respondents were married $81.2 \%$. The range of workers old was 22 thru 48 years and the majority of participants tenure is $0-5$ years $32.4 \%$.

\section{Measures}

\subsection{Organizational Silence Climate}

Vakola and Bouradas organizational silence climate survey was administered. The scale consists of 13 items. 3 items measures of Top Management attitude to silence behavior; 5 items measures of Supervisor attitude to silence behavior and 5 items measures of communication opportunities. Variance explained ratio was 61.457. Factor loads for all sub-dimensions were attained between .612 thru .861. Cronbach's alpha coefficients were $.772 ; 824$; and 731 respectively.

\subsection{Employee Silence Behavior}

Employee Silence Behavior scale which was defined by Dyne et al. (2003) was administered. This scale consists of three factor which are Self-Protective Silence ( 9 items), Acquiescent Silence (9 items) and Prosocial Silence (5 items). Variance explained ratio was 67.557. Factor loads for all sub-dimensions were attained between .542 thru .819. Cronbach's alpha coefficients were $.891 ; 927$; and 862 respectively.

\subsection{Job Satisfaction}

Brown and Peterson' (1994) job satisfaction survey was used. The scale consists of 6 items. Participants were requested to evaluate each item in terms of the frequency of their feelings ranging from 1 (strongly disagree) to 5 (strongly agree). Variance explained ratio was 59.954. Factor loads for all sub-dimensions were attained between .687 thru .741 . Cronbach's alpha coefficients were .853 .

\subsection{Stress}

Stress was measured by using the scale developed by House and Rizzo (1972). The scale has 7 factors. Participants were asked to respond to stress scale by indicating the degree to which the condition applied to them on a five-point scale ranging from 1 (strongly disagree) to 5 (strongly agree). In this sample, Variance explained ratio was 63.090. Factor loads for all sub-dimension were attained between .540 thru .894 . Cronbach's alpha coefficients were .898 .

\section{Results}

The inter correlation matrix results were showed in Table 1. According to results from Table 1, Job satisfaction variable has only positive relation with supervisory attitude to silence and communication opportunities and negative relation with stress. And stress has a positive relation with Acquiescent Silence, Self-Protective Silence, Pro-social Silence which means that employee behavior to silence directly results in stress. Communication 
opportunities have only positive relationship with supervisory attitude to silence. All results means that Organization silence climate directly shape and effect of employee silence behavior, then employee silence behavior might carry these influence on job satisfaction and stress in organization.

Table 1. Correlation results

\begin{tabular}{|c|c|c|c|c|c|c|c|c|}
\hline & 1 & 2 & 3 & 4 & 5 & 6 & 7 & 8 \\
\hline 1. Job satisfaction & 1 & & & & & & & \\
\hline 2. stress &,$- 252^{* *}$ & 1 & & & & & & \\
\hline 3. Top management attitude to silence &,- 056 &, $289^{* *}$ & 1 & & & & & \\
\hline 4. Supervisor attitude to silence &, $297^{* *}$ &,- 098 &,- 020 & 1 & & & & \\
\hline 5.Communication opportunities &, $318^{* *}$ &,- 053 &, 043 &, $651^{* * *}$ & 1 & & & \\
\hline 6. Acquiescent Silence &, 033 &, $180^{*}$ &, $483^{* *}$ &, 028 &, 190 ** & 1 & & \\
\hline 7. Self-Protective Silence &,- 047 &, $\mathbf{3 1 3}^{* *}$ &, $491^{* *}$ &, 050 &, 138 &, $\mathbf{8 2 3}^{* *}$ & 1 & \\
\hline 8. Pro-social Silence &, 126 &, $182^{*}$ &, $\mathbf{3 3 5}^{* *}$ &, $220^{* *}$ &, $281^{* *}$ &, $548^{* *}$ &, $618^{* *}$ & 1 \\
\hline
\end{tabular}

Note. $*$ Correlation is significant at the 0.01 level (2-tailed). $*$ Correlation is significant at the 0.05 level (2-tailed).

In the Table 2 results, thereare positive regression relationship found between Acquiescent Silence and Self Protective Silence with top management attitude to silence and communication opportunities. Also positive relationship was found between Pro-social silence, top management attitude to silence, supervisory attitude to silence and communication opportunities. According to Table 1 and 2 results, $\mathrm{h}_{1}$ was supported.

Table 2. Regression analysis between organizational silences climate and fear and silence behavior

\begin{tabular}{lllllll}
\hline variables & Adjusted R squared & Std. Error & F & t & Beta & Sig. \\
\hline Top management attitude to silence & .234 & .77488 & 59.728 & 7.728 & $\mathbf{. 4 8 3}$ & $\mathbf{. 0 0 0}$ \\
Supervisor attitude to silence & .001 & .88476 & .152 & .390 & .028 & .697 \\
Communication opportunities & .031 & .86894 & 7.360 & 2.713 &. $\mathbf{1 9 0}$ & $\mathbf{. 0 0 7}$ \\
Dependent variable: Acquiescent Silence & & & & & & \\
\hline variables & Adjusted R squared & Std. Error & F & t & Beta & Sig. \\
\hline Top management attitude to silence & .237 & .82851 & 62.343 & 7.896 & $\mathbf{. 4 9 1}$ & $\mathbf{. 0 0 0}$ \\
Supervisor attitude to silence & .002 & .95001 & .490 & .700 & .050 & .485 \\
Communication opportunities & .014 & .94211 & 3.796 & 1.948 & $\mathbf{. 1 3 8}$ & $\mathbf{. 0 5 3}$ \\
Dependent variable: Self Protective Silence & & & & & & Sig. \\
\hline variables & Adjusted R squared & Std. Error & F & t & Beta & Sig \\
\hline Top management attitude to silence & .108 & .86242 & 24.819 & 4.982 & $\mathbf{. 3 3 5}$ & $\mathbf{. 0 0 0}$ \\
Supervisor attitude to silence & .049 & .89291 & 9.998 & 3.162 & $\mathbf{. 2 2 0}$ & $\mathbf{. 0 0 2}$ \\
Communication opportunities & .079 & .87839 & 16.865 & 4.107 & $\mathbf{. 2 8 1}$ & $\mathbf{. 0 0 0}$ \\
Dependent variable: Pro-social Silence & & & & & & \\
\hline
\end{tabular}

In the concept of this study there was an attempt to understand how employee silence behavior results in the consequences such as job satisfaction and stress. The results showed that job satisfaction were not affected by the employee silence behavior but stress. 
Table 3. Regression analysis between fear and silence behavior, job satisfaction and stress

\begin{tabular}{lllllll}
\hline variables & Adjusted R squared & Std. Error & $\mathrm{F}$ & $\mathrm{t}$ & $\mathrm{Beta}$ & Sig. \\
\hline Acquiescent silence & -.004 & .80176 & .211 & .459 & .033 & .646 \\
Self-Protective Silence & -.003 & .80132 & .427 & -.654 & -.047 & .514 \\
Pro-social Silence & .011 & .79578 & 3.171 & 1.781 & .126 & .077 \\
Dependent variable: Job satisfaction & & & & & & \\
\hline variables & Adjusted R squared & Std. Error & $\mathrm{F}$ & $\mathrm{t}$ & $\mathrm{Beta}$ & Sig. \\
\hline Acquiescent silence & .027 & .87356 & 6.532 & 2.556 & $\mathbf{. 1 8 0}$ & $\mathbf{. 0 1 1}$ \\
Self-Protective Silence & .093 & .84347 & 21.242 & 4.609 & $\mathbf{. 3 1 3}$ & $\mathbf{. 0 0 0}$ \\
Pro-social Silence & .028 & .87317 & 6.716 & 2.592 & $\mathbf{. 1 8 2}$ & $\mathbf{. 0 1 0}$ \\
Dependent variable: Stress & & & & & & \\
\hline
\end{tabular}

\section{Discussion}

This study aimed to examine the relationship among organizational silence climate, employees' silence behavior, stress and job satisfaction. Results showed that there is a positive relationship found between Acquiescent silence and Self-Protective Silence with top management attitudes to silence, communication opportunities; Pro-social Silence has a positive relationship with top management to silence, supervisor management to silence and communication opportunities. Job satisfaction has no relationship with employee silence behavior dimension such as Acquiescent silence, Self-Protective Silence, Pro-social Silence. But it has a negative relationship with stress. And also it has positive relations with supervisor attitude to silence and communication opportunities.

In this study, there is a discrepancy exist between finding in this study with findings which were attained by Morrison and Milliken (2000). In Morrison and Milliken (2000) study, they found that supervisory attitude to silence behavior was the strongest predictor of silence behavior. But in this study, top manager attitude to silence is the strongest predictor of silence behavior in organization. This might happen due to working environment. This study was conducted in school. There might not be supervisor who was used as effective as the supervisor in Morrison and Milliken (2000) study. And employee might directly interact with their top managers. But most of the other findings are consistent with the relevant proposition by Morrison and Milliken (2000). It would be said that top and supervisory attitude to silence influence the silence behavior in organization. This means that employee directly look their first managers to understand how to express their idea or different opinions, their disagreement, or to resist unwanted requirement. If the first managers give employee right to speak up and also support them multi-channel communication opportunities, they will feel free to voice up, discuss, participate the decision making process. This way organization can benefit of employee experiences and knowledge.

The results of the study also showed that the strongest predictor of job satisfaction is communication opportunities. Past research supports this finding indicating that communication among other organizational processes is a predictor of job satisfaction (Putti \& Aryee, 1990). This happens because satisfaction with openness in communication channels, trust and sharing of information and knowledge may all enhance a sense of belonging and identification with the organization. This may also indicate that supervisors' attitudes and top management attitudes to silence are important as jobs satisfaction developer.

This study findings support that top or supervisory attitude to silence are both the strongest predictor of job satisfaction if both managers give opportunities to employee to change their idea, handle problems, pay attention their opinions, employee might feel more satisfied with their job (Willkinson \& Wagner, 1993; Mishra \& Morrissey, 1990; Rich, 1997).

\section{References}

Blatt, R., Christianson, M. K., Sutcliffe, K. M., \& Rosenthal, M. M. (2006). A sensemaking lens on reliability. Journal of Organizational Behaviour, 27(7), 897-917. http://dx.doi.org/10.1002/job.392

Botero, I. C., \& Dyne, L. V. (2009). Employee voice behavior: Interactive effects of LMX and power distance in the United States and Colombia. Management Communication Quarterly, 23(1), 84-104. http://dx.doi.org/10.1177/0893318909335415

Bowen, F., \& Blackmon, K. (2003). Spirals of silence: The dynamic effects of diversity on organizational voice. 
Journal of Management Studies, 40, 1393-1417. http://dx.doi.org/10.1111/1467-6486.00385

Breen, V., Fetzer, R., Howard, L., \& Preziosi, R. (2005). Consensus problem: Solving increases perceived communication openness in organizations. Employee Responsibilities and Rights Journal, 17(4), 215-229. http://dx.doi.org/10.1007/s10672-005-9050-z

Brown, S. P., \& Peterson, R. A. (1994). The effect of effort on sales performance and job satisfaction. Journal of Marketing, 58(2). ABI/INFORM Global. http://dx.doi.org/10.2307/1252270

Duton, J. E., \& Sussan, E. A. (1999). Selling issues to top management. Academic of Management Review, 18.

Gephart, J. J. K., Detert, J. R., Trevin, L. K. E., \& Amy, C. (2009). Silenced by fear: The nature, sources, and consequences of fear at work. Research in Organizational Behavior, 29, 1-31. http://dx.doi.org/10.1016/j.riob.2009.07.001

Grenville, H., \& Jennifer, A. (2007). Developing issue-selling effectiveness over time: Issue selling as resourcing. Organization Science, 18(4), 560-577. http://dx.doi.org/10.1287/orsc.1070.0266

House, R., \& Rizzo, J. (1972). Role conflict and ambiguity as critical variables in a model of organizational behavior. Organizational Behavior and Human Performance, 7, 467-505. http://dx.doi.org/10.1016/0030-5073(72)90030-X

Johlke, M. C., \& Duhan, D. F. (2000). Supervisor communication practices and service employee job outcomes. Journal of Service Research, 3(2), 154-165. http://dx.doi.org/10.1177/109467050032004

Mayhew, M. J., Grunwald, H. E., \& Dey, E. L. (2006). Breaking the silence: Achieving a positive climate for diversity from the staff perspective. Research in Higher Education, 47(1), 63-88. http://dx.doi.org/10.1007/s11162-004-8152-z

Milliken, F. J., Morrison, E. W., \& Hewlin, P. F. (2003). An exploratory study of employee silence: Issues that employees don't communicate upward and why. Journal of Management Studies, 40, 1453-1476. http://dx.doi.org/10.1111/1467-6486.00387

Mishra, J., \& Morrissey, M. A. (1990). Trust in employee/employer relationships: A survey of West Michigan managers. Public Personnel Management, 19, 443-485.

Morrison, E. W., \& Milliken, F. J. (2000). Organizational silence: A barrier to change and development in a pluralistic world. Academy of Management Review, 25, 706-725. http://dx.doi.org/10.2307/259200

Nemeth, C. J., \& Staw, B. M. (1989). The tradeoffs of social control and innovation in small groups and organizations. In L. Berkowitz (Ed.), Advances in experimental social psychology (Vol. 22, pp. 175-210). New York: Academic Press.

Perlow, L., \& Williams, S. (2003, May). Is silence killing your company? Harvard Business Review, 81, 52-58. http://dx.doi.org/10.1109/EMR.2003.24935

Pinder, C. C., \& Harlos, K. P. (2001). Employee silence: Quiescence and acquiescence as responses to perceived injustice. Research in Personnel and Human Resources Management, 20, 331-369. http://dx.doi.org/10.1016/S0742-7301(01)20007-3

Premeaux, S. F. (2001). Breaking the Silence: Toward an understanding of speaking up in the workplace. Unpublished Doctoral Thesis, Louisiana State University.

Premeaux, S. F., \& Bedeian, A. G. (2003). Breaking the silence: The moderating effects of elf monitoring in predicting speaking up in the workplace. Journal of Management Studies, 40, 1537-1562. http://dx.doi.org/10.1111/1467-6486.00390

Putti, J., \& Aryee, S. (1990). Communication relationship satisfaction. Group and Organization Studies, 15(1), 44-53. http://dx.doi.org/10.1177/105960119001500104

Rich, G. (1997). The sales manager as a role model: Effects on trust, job satisfaction and performance of

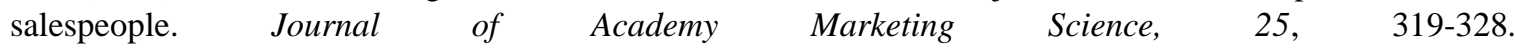
http://dx.doi.org/10.1177/0092070397254004

Ruppel, C. P., \& Harrinton, S. J. (2000). The relationship of communication, ethical work climate, and trust to commitment and innovation. Journal of Business Ethics, 25(4), 313-328. http://dx.doi.org/10.1023/A:1006290432594

Schlenker, B. R., \& Weigold, M. F. (1989). Self-Identification and Accountability. In R. A. Giacalone \& P. Rosenfeld (Eds.), Impression management in the organization (pp. 21-43). Hillsdale, NJ: Erlbaum. 
Slade M. R. (2008). The adaptive nature of organizational silence: A cybernetic exploration of the hidden factory. Unpublished Doctoral Thesis, George Washington University.

Sussman, L. (2008). Disclosure, leaks, and slips: Issues and strategies for prohibiting employee communication. Business Horizons, 51(4). http://dx.doi.org/10.1016/j.bushor.2008.02.006

Tangirala, S., \& Ramanujam, R. (2008). Employee silence on critical work issues: The cross level effects of $\begin{array}{llll}\text { procedural justice } & \text { climate. Personnel }\end{array}$ http://dx.doi.org/10.1111/j.1744-6570.2008.00105.x

Van Dyne, L., Ang, S., \& Botero, I. C. (2003). Conceptualizing employee silence and employee voice as multidimensional constructs. Journal of Management Studies, 40, 1359-1392. http://dx.doi.org/10.1111/1467-6486.00384

Vokola, M., \& Bouradas, D. (2005). Antecedents and consequences of organizational silence: An empirical investigation. Employee Relations, 27(5), 441-458. http://dx.doi.org/10.1108/01425450510611997

Willkinson, A., \& Wagner, R. (1993). Supervisory leadership styles and state vocational rehabilitation counselor job satisfaction and productivity. Rehabilitation Counselling Bulletin, 37(1), 15-25.

\section{Copyrights}

Copyright for this article is retained by the author(s), with first publication rights granted to the journal.

This is an open-access article distributed under the terms and conditions of the Creative Commons Attribution license (http://creativecommons.org/licenses/by/3.0/). 